\title{
Spores of Beauveria bassiana and Trichoderma lignorum as a bioinsecticide for the control of Atta cephalotes
}

\author{
Fabian Felipe Fernandez Daza', Ginna Rodriguez Roman', Marino Valencia Rodriguez², \\ Ivan Andres Gonzalez Vargas ${ }^{3}$, Heiber Cardenas Heano ${ }^{4}$, Marney Pascoli Cereda ${ }^{5}$ \\ and Raul Alberto Cuervo Mulet ${ }^{1^{*}}$ (D)
}

\begin{abstract}
Background: The leafcutter ant (Atta cephalotes) is associated with losses in the agricultural sector, due to its defoliating activity; for its control, biological, mechanical and chemical methods have been developed, the latter associated with adverse effects on human and environmental health. This research validated in the field for the control of the leafcutter ant (A. cephalotes) using a mixture of Beauveria bassiana and Trichoderma lignorum spores.

Methods: The effectiveness from the combination of spores of B. bassiana and T. lignorum with an initial concentration of $2 \times 10^{9}$ spores $/ \mathrm{ml}$, in the following proportions of $B$. bassiana and T. lignorum, A (1:1), of each fungus. It was evaluated within the university campus, comparing it with two commercial formulations, Mycotrol (B. bassiana) and Mycobac (T. lignorum). Additionally, this formulation was evaluated in 49 nests distributed 16 in 14 locations in Colombia. The formulation application was carried out by direct application, using a pump at a speed of $10 \mathrm{ml} / \mathrm{m}^{2}$. The effectiveness was estimated from the reduction of the flow of ants, evaluating the statistically significant differences using the ANOVA and Tukey-test.

Results: Effective control of $90 \%$ of the nests was observed in the field phase in 60 days, except in nests with areas $>50 \mathrm{~m}^{2}$ that were located in regions with high rainfall (annual average precipitation above $7000 \mathrm{~mm}$ ), such as Buenaventura.
\end{abstract}

Conclusions: In this work, it was demonstrated that the combination of B. bassiana and T. lignorum spores represent a viable alternative for the control of the leafcutter ant, in which the effectiveness is related to several factors, including the size of the nest and the rainfall in the area.

Keywords: Entomopathogenic fungi, Biological control, Bioinsecticide, Biological risk, Field validation

\section{Background}

The leafcutter ant Atta cephalotes (Linnaeus, 1758) is distributed throughout Colombia, especially in the Pacific and Andean regions. Due to their defoliating activity, $A$. cephalotes affects crops such as cotton (Gossypium L.), cocoa (Theobroma cacao L.), yucca (Manihot esculenta Crantz), corn (Zea mays L.), rubber (Hevea brasiliensis

\footnotetext{
*Correspondence: racuervo@usbcali.edu.co

1 Biotechnology Group, Universidad de San Buenaventura-Cali, Av 122\# 6-65, Cali 76001, Colombia

Full list of author information is available at the end of the article
}

Mull. Arg.), sugar cane (Saccharum officinarum L.) and citrus fruits $[1,2]$ and is considered a pest species. It is estimated that $A$. cephalotes can consume between 50 and $150 \mathrm{~kg}$ of plant material per day. In addition, damage to buildings and roads has been reported due to the destabilization of soils from the removal of land during the construction of nests [3].

To control leafcutter ants, mechanical, chemical and biological methods have been developed. Mechanical control consist of the removal of the nests with the extraction of the queen ant and the destruction of the 
breeding chambers; this method has an effectiveness of approximately $30 \%$ [3]. Chemical control is based on the application of insecticides, which generally have the active components sulfluramid, fipronil, deltamethrin, chlorpyrifos and fenitrothion. These insecticides may present risks to human health $[4,5]$, may cause problems associated with bio-concentration, bio-accumulation and bio-magnification in ecosystems [6-8], and may be associated with the development of resistance in economic impact pests such as ticks [Rhipicephalus (Boophilus) microplus] [5], mites (Phenacoccus solenopsis) [9] and fire ants (Solenopsis invicta) [10]. In some cases, these pesticides are applied by thermal fogging, which increases soil contamination and does not affect all of the ants in the nest. Biological methods include the application of plant extracts $[11,12]$ and the use of trapping crops [13], which temporarily reduce the population of the nest without definitively eliminating it; thus, the accompaniment of other control mechanisms to improve effectiveness is recommended [3].

For all of the above reasons, the use of biological controls in agriculture has grown continuously, especially biocontrols composed of the spores of filamentous fungi such as Beauveria bassiana, an entomopathogenic fungus, which infects the insect by adhesion to the cuticle insect host by adhesion proteins (Mad 1, Mad 2-Adhesin-like proteins; Hyd 1, Hyd 2, Hyd 3-Hydrophobins [14, 15], followed of the formation of the appressorium, which generates the breakdown of chitin by means of a combination of mechanical strength and enzymatic degradation (proteases, chitinases and lipases) [16], which also focuses enzymatic activity through the production of a mucilage on the site of contact, isolating the point from the outside [17]. The evasion of the immune system is mediated by the expression of Mcl1 proteins [18], the secretion of destruxins A and E, production of trehalase and expression of faith genes involved in the cycle cell, allowing rapid multiplication and differentiation of hyphae in the host's hemolymph, leading to host mummification [14, 19-21]. On the other hand, the Trichoderma genus is characterized by its Mycoparasite activity, which is initiated by the chemotropic growth towards the host that is recognized through lectin-carbohydrate interactions [22-25]. The adhesion of the hyphae is done by the formation of appressoria, wrapping around the hypha of the infected fungus to which they adhere to the hyphae, and where it usually covers and penetrates the hyphae of the parasitized fungus, followed by degradation of the cell walls, which occurs due to the production of extracellular lytic enzymes (chitinases, glucanase, xylanase, $\mathrm{N}$-acetylglucosaminidase, and proteases), which is regulated by the MAPK pathway [26]; These enzymes degrade the cell walls of the host and allow the penetration of the antagonist hyphae, thus forming pores allowing access to the cytoplasm, from which it will extract the nutrients required for its development [27].

Due to the negative impact of leafcutter ants on food security as well as the impact on local economies, we evaluated a bioinsecticide composed of the spores of $B$. Bassiana (ATCC MYA-4886) and Trichoderma lignorum (ATCC 8751) for the control of the leafcutter ant (Atta cephalotes) under field conditions.

\section{Methodology}

In this study, strains of B. bassiana (ATCC MYA-4886) and T. lignorum (ATCC 8751) were grown in PDA medium (agar, potato, dextrose) and were incubated at $28 \pm 1{ }^{\circ} \mathrm{C}$ for 5 days. The spores were collected by scraping the surface and deposited into the YPD medium (yeast extract, peptone, dextrose). A concentration $1 \times 10^{6}$ spores $/ \mathrm{ml}$ is confirmed using a Neubauer hemocytometer [28], to prepared the inoculum $(500 \mathrm{ml})$. The inoculum was placed in the fermenter (BIOSTAT ${ }^{\circledR}$ B), Adding YPD, up to 41 and grown by 4 days at $20 \mathrm{rpm}$ of agitation, $30{ }^{\circ} \mathrm{C}$ and pH 5.4 $[29,30]$. Every $24 \mathrm{~h}$ sample of $5 \mathrm{ml}$ was taken for the spore count and grown in PDA medium used for the identified accord to the key described by Barnett and Hunter [31]. Finally, it is centrifuged at $8000 \mathrm{rpm}$ for $15 \mathrm{~min}$, discarding the supernatant, washing the spores and storing them in sterile distilled water.

The formulation used was the combination of spores of B. bassiana and T. lignorum with an initial concentration of $2 \times 10^{9}$ spores/ml which include Twen20, Sorbitol, Sodium saccharin, Sodium benzoate, Citric acid, Methylparaben and sodium cyclamate. Viability, purity, pathogenicity, and $\mathrm{pH}$ of the formulation are described in Fernandez et al. [32].

\section{Tests: University campus}

This phase was carried out in 11 nests (Table 1) present on the campus of the University of San Buenaventura-Cali. We inoculated $10 \mathrm{ml} / \mathrm{m}^{2}$ of the following solutions at weeks 2, 7 and 11: Mycotrol (B. bassiana), Mycobac (T. lignorum), and the formulation with the greatest pathogenicity at a final concentration of $1 \times 10^{9} \mathrm{conidia} / \mathrm{ml}$. For each nest, the flow of ants was estimated [33-35], measured as the number of ants that emerged over 5 min intervals (from 5:00 to 6:00 p.m.). Each count was performed in triplicate, daily for 14 weeks. Nest areas were also estimated.

\section{Field phase}

This phase was carried out to observe the reproducibility of the university campus test, in different regions of Colombia. The external field tests were performed in 49 nests in 14 Colombian localities with different 
Table 1 Characteristics of the nests used for the Tests on university campus

\begin{tabular}{|c|c|c|c|c|c|c|c|c|c|c|c|}
\hline \multirow[t]{2}{*}{ Characteristics } & \multicolumn{3}{|c|}{ Mycotrol } & \multicolumn{3}{|c|}{ Mycobac } & \multicolumn{2}{|c|}{ Control } & \multicolumn{3}{|c|}{ Formulation A } \\
\hline & R1 & $\mathrm{R} 2$ & R3 & R4 & R5 & $\mathrm{R} 6$ & $\mathrm{R7}$ & R8 & $\mathrm{R} 9$ & R10 & R11 \\
\hline Length & 7.23 & 6.45 & 8.33 & 4.57 & 5.6 & 6.2 & 7.25 & 6.23 & 6.32 & 4.15 & 5.43 \\
\hline Width & 3.15 & 2.78 & 4.12 & 3.37 & 3.17 & 3.30 & 2.8 & 4.27 & 2.75 & 4.76 & 3.86 \\
\hline Area $\left(m^{2}\right)$ & 22.77 & 17.93 & 34.32 & 15.40 & 17.75 & 20.56 & 20.3 & 26.60 & 17.38 & 19.754 & 20.96 \\
\hline
\end{tabular}

$R$ nest evaluated

soils, climates (temperature) and rainfall (precipitation) (Table 2). The experimental bioinsecticide (formulation A) was applied as previously described. The effectiveness was estimated as the average flow of ants (percentage), calculated as the ratio of initial percentage to the final observed percentage for each period (week 4, 8 and 12). Additionally, the intervened nests were classified according to area (small, $<10 \mathrm{~m}^{2}$; medium, $10 \mathrm{~m}^{2}$ to $<50 \mathrm{~m}^{2}$; and large, $>50 \mathrm{~m}^{2}$ ), and 14 nests (to which the bioinsecticide was not applied) were included as a negative control. At the end of the monitoring phase (12 weeks), 14 dead individuals were collected, which were deposited into Petri dishes containing PDA and YPDA and were incubated for 10 days at $30^{\circ} \mathrm{C}$. Plates were monitored for fungal growth.

\section{Analysis of results}

In tests: University campus and field phase, each nest subjected to the same treatment was considered a replicate, and each subjected ant flow (performed in triplicate each day, for 14 weeks) was considered a repetition. The treatment efficacy was estimated as the percentage value of the ratio between post-exposure and pre-exposure ant flow. The differences between the treatments were evaluated by analysis of variance (ANOVA) and Tukey's test $(\alpha=0.05)$ (SPSS 20.0.) using the average daily ant flow counts, obtained for each week in the field tests, with previous compliance of the assumptions of variance homogeneity and normal distribution.

\section{Ethical considerations}

For the execution of this investigation, the ethical endorsement Ing7I15 was granted by the research ethics committee of the university of San Buenaventura-Cali. Animal ethics endorsement was granted by the CIECUAE committee of the university ICESI no. 0023 of 2017.

\section{Results}

\section{Tests: University campus}

A total of 11 nests were tested, in which $50 \%$ had three exits and entrances. The nests had an average length of
$5.86 \mathrm{~m}$, an average width of $3.38 \mathrm{~m}$, and mound areas between 15 and $23 \mathrm{~m}^{2}$. The temperature was maintained in a range between 22 and $32{ }^{\circ} \mathrm{C}$. We observed a flow of ants between 90 and 103, which were average values for week 1 (without inoculation). The greatest reduction in the flow of ants compared to the initial flow was observed during weeks 6 (29.54\% to 52.26), $12(66 \%$ to $97 \%)$ and 14 (87.9 to $100 \%)$, and an increase of 30.6 ants was observed in the controls. The greatest effectiveness corresponded to formulation A (spores of B. bassiana and T. lignorum, patent A01N 65/00), showing statistically significant differences between the control and the different treatments commercial bioformulations Mycontrol (B. bassiana) and Mycobac (T. lignorum), evaluated in the local field test (Table 3).

\section{Field phase}

We observed differences in effectiveness associated with nest size in regions where eradication of nests $>10 \mathrm{~m}^{2}$ was achieved in an average of 4 weeks (30 days), eradication of medium-sized nests was achieved in 8 weeks (60 days), and a reduction of at least $20 \%$ of ants in large nests was recorded after 8 weeks, which exhibited no ant flow after 12 weeks. The variations among the groupings between nest sizes was associated with differences between them in each locality (Table 4), in contrast to the nests from the localities of Buenaventura, Lloró and Atrato, where the bioinsecticide was not effective.

\section{Discussion}

In the present study, it was demonstrated that treatment with a formulation containing conidia of $B$. bassiana and T. lignorum presents insecticidal activity against $A$. cephalotes and can be considered for the control of this agricultural pest. Control the leafcutter ant (A. cephalotes) can be achieved by controlling/eliminating the food source (Leucoagaricus gongylophorus [36]), or the queen; unique for each anthill, responsible for generating the individuals [11] of the different castes required for the operation of the anthill [37]. The tests: University campus showed that formulation $\mathrm{A}$, achieved a reduction in the 
Table 2 Geographical distribution of intervened nests in field test

\begin{tabular}{|c|c|c|c|c|c|c|}
\hline Department & Location & Elevation (masl) & Annual rainfall & R. $\mathrm{H}$ & $\mathrm{T}\left({ }^{\circ} \mathrm{C}\right)$ & Coordinates of intervened nests \\
\hline \multirow[t]{2}{*}{ Choco } & Lloró & 65 & 7774 & 84 & 26.9 & $\begin{array}{l}5^{\circ} 29^{\prime} 46.0^{\prime \prime} \mathrm{N} 76^{\circ} 32^{\prime} 06.5^{\prime \prime} \mathrm{W} \\
5^{\circ} 29^{\prime} 59.0^{\prime \prime} \mathrm{N} 76^{\circ} 32^{\prime} 19.7^{\prime \prime} \mathrm{W} \\
5^{\circ} 30^{\prime} 53.3^{\prime \prime} \mathrm{N} 76^{\circ} 32^{\prime} 32.9^{\prime \prime} \mathrm{W} \\
5^{\circ} 31^{\prime} 11.7^{\prime \prime} \mathrm{N} 76^{\circ} 32^{\prime} 36.1^{\prime \prime} \mathrm{W}\end{array}$ \\
\hline & Atrato & 43 & 12,000 & 84 & 30 & $\begin{array}{l}5^{\circ} 31^{\prime} 30.5^{\prime \prime} \mathrm{N} 76^{\circ} 38^{\prime} 08.6^{\prime \prime} \mathrm{W} \\
5^{\circ} 31^{\prime} 54.1^{\prime \prime} \mathrm{N} 76^{\circ} 38^{\prime} 29.4^{\prime \prime} \mathrm{W} \\
5^{\circ} 31^{\prime} 47.9^{\prime \prime} \mathrm{N} 76^{\circ} 38^{\prime} 34.9^{\prime \prime} \mathrm{W}\end{array}$ \\
\hline \multirow[t]{3}{*}{ Valle del Cauca } & Buenaventura & 7 & 7328 & 60 & 30 & $\begin{array}{l}3^{\circ} 57^{\prime} 14.8^{\prime \prime} \mathrm{N} 76^{\circ} 58^{\prime} 45.4^{\prime \prime} \mathrm{W} \\
4^{\circ} 00^{\prime} 00.3^{\prime \prime} \mathrm{N} 76^{\circ} 57^{\prime} 33.7^{\prime \prime} \mathrm{W} \\
3^{\circ} 59^{\prime} 50.1^{\prime \prime} \mathrm{N} 76^{\circ} 58^{\prime} 45.4^{\prime \prime} \mathrm{W}\end{array}$ \\
\hline & Bugalagrande & 941 & 941 & 40 & 28 & $\begin{array}{l}4^{\circ} 11^{\prime} 27.7^{\prime \prime} \mathrm{N} 76^{\circ} 10^{\prime} 07.6^{\prime \prime} \mathrm{W} \\
4^{\circ} 12^{\prime} 59.5^{\prime \prime} \mathrm{N} 76^{\circ} 09^{\prime} 15.5^{\prime \prime} \mathrm{W} \\
4^{\circ} 11^{\prime} 42.1^{\prime \prime} \mathrm{N} 76^{\circ} 09^{\prime} 50.9^{\prime \prime} \mathrm{W}\end{array}$ \\
\hline & Caicedonia & 1100 & 1872 & 60 & 22.4 & $\begin{array}{l}4^{\circ} 19^{\prime} 48.7^{\prime \prime} \mathrm{N} 75^{\circ} 48^{\prime} 42.7^{\prime \prime} \mathrm{W} \\
4^{\circ} 20^{\prime} 06.6^{\prime \prime} \mathrm{N} 75^{\circ} 48^{\prime} 48.4^{\prime \prime} \mathrm{W} \\
4^{\circ} 19^{\prime} 27.7^{\prime \prime} \mathrm{N} 75^{\circ} 48^{\prime} 58.4^{\prime \prime} \mathrm{W}\end{array}$ \\
\hline \multirow[t]{2}{*}{ Antioquia } & Yolombo & 1450 & 2837 & 57 & 21 & $\begin{array}{l}6^{\circ} 36^{\prime} 49.7^{\prime \prime} \mathrm{N} 74^{\circ} 59^{\prime} 46.5^{\prime \prime} \mathrm{W} \\
6^{\circ} 35^{\prime} 07.5^{\prime \prime} \mathrm{N} 74^{\circ} 58^{\prime} 30.2^{\prime \prime} \mathrm{W} \\
6^{\circ} 35^{\prime} 24.4^{\prime \prime} \mathrm{N} 74^{\circ} 58^{\prime} 12.1^{\prime \prime} \mathrm{W}\end{array}$ \\
\hline & Girardota & 1425 & 1821 & 89 & 22.2 & $\begin{array}{l}6^{\circ} 23^{\prime} 06.4^{\prime \prime} \mathrm{N} 75^{\circ} 27^{\prime} 47.8^{\prime \prime} \mathrm{W} \\
6^{\circ} 23^{\prime} 20.3^{\prime \prime} \mathrm{N} 75^{\circ} 26^{\prime} 55.8^{\prime \prime} \mathrm{W} \\
6^{\circ} 22^{\prime} 30.5^{\prime \prime} \mathrm{N} 75^{\circ} 27^{\prime} 00.6^{\prime \prime} \mathrm{W} \\
6^{\circ} 22^{\prime} 44.8^{\prime \prime} \mathrm{N} 75^{\circ} 26^{\prime} 45.6^{\prime \prime} \mathrm{W}\end{array}$ \\
\hline \multirow[t]{3}{*}{ Huila } & Tesalia & 830 & 1495 & 71 & 23.7 & $\begin{array}{l}2^{\circ} 29^{\prime} 10.1^{\prime \prime} \mathrm{N} 75^{\circ} 43^{\prime} 02.0^{\prime \prime} \mathrm{W} \\
2^{\circ} 29^{\prime} 08.7^{\prime \prime} \mathrm{N} 75^{\circ} 43^{\prime} 03.6^{\prime \prime} \mathrm{W} \\
2^{\circ} 28^{\prime} 33.7^{\prime \prime} \mathrm{N} 75^{\circ} 44^{\prime} 23.3^{\prime \prime} \mathrm{W} \\
2^{\circ} 28^{\prime} 33.3^{\prime \prime} \mathrm{N} 75^{\circ} 44^{\prime} 23.7^{\prime \prime} \mathrm{W}\end{array}$ \\
\hline & La Argentina & 1560 & 1813 & NA & 18 & $\begin{array}{l}2^{\circ} 11^{\prime} 39.1^{\prime \prime} \mathrm{N} 75^{\circ} 59^{\prime} 18.1^{\prime \prime} \mathrm{W} \\
2^{\circ} 12^{\prime} 15.2^{\prime \prime} \mathrm{N} 75^{\circ} 58^{\prime} 35.3^{\prime \prime} \mathrm{W} \\
2^{\circ} 12^{\prime} 42.2^{\prime \prime} \mathrm{N} 75^{\circ} 58^{\prime} 35.0^{\prime \prime} \mathrm{W}\end{array}$ \\
\hline & La plata & 1050 & 1499 & 68 & 22.7 & $\begin{array}{l}2^{\circ} 27^{\prime} 34.1^{\prime \prime} \mathrm{N} 75^{\circ} 50^{\prime} 08.0^{\prime \prime} \mathrm{W} \\
2^{\circ} 22^{\prime} 08.3^{\prime \prime} \mathrm{N} 75^{\circ} 54^{\prime} 28.3^{\prime \prime} \mathrm{W} \\
2^{\circ} 22^{\prime} 09.6^{\prime \prime} \mathrm{N} 75^{\circ} 54^{\prime} 32.3^{\prime \prime} \mathrm{W}\end{array}$ \\
\hline Cundinamarca & Tocaima & 400 & 1260 & NA & 27 & $\begin{array}{l}4^{\circ} 27^{\prime} 12.2^{\prime \prime} \mathrm{N} 74^{\circ} 37^{\prime} 11.0^{\prime \prime} \mathrm{W} \\
4^{\circ} 27^{\prime} 05.5^{\prime \prime} \mathrm{N} 74^{\circ} 38^{\prime} 23.7^{\prime \prime} \mathrm{W} \\
4^{\circ} 25^{\prime} 47.0^{\prime \prime} \mathrm{N} 74^{\circ} 38^{\prime} 49.8^{\prime \prime} \mathrm{W} \\
4^{\circ} 26^{\prime} 19.9^{\prime \prime} \mathrm{N} 74^{\circ} 37^{\prime} 55.5^{\prime \prime} \mathrm{W}\end{array}$ \\
\hline Sucre & Sincelejo & 213 & 1164 & 54 & 26.6 & $\begin{array}{l}9^{\circ} 18^{\prime} 24.4^{\prime \prime} \mathrm{N} 75^{\circ} 21^{\prime} 29.1^{\prime \prime} \mathrm{W} \\
9^{\circ} 18^{\prime} 01.0^{\prime \prime} \mathrm{N} 75^{\circ} 21^{\prime} 35.8^{\prime \prime} \mathrm{W}\end{array}$ \\
\hline Magdalena & Santa Marta & 2 & 512 & 52 & 28.3 & $\begin{array}{l}11^{\circ} 17^{\prime} 33.7^{\prime \prime} \mathrm{N} 4^{\circ} 00^{\prime} 01.5^{\prime \prime} \mathrm{W} \\
11^{\circ} 17^{\prime} 37.5^{\prime \prime} \mathrm{N} 4^{\circ} 00^{\prime} 00.8^{\prime \prime} \mathrm{W} \\
11^{\circ} 17^{\prime} 40.8^{\prime \prime} \mathrm{N} 4^{\circ} 00^{\prime} 00.9^{\prime \prime} \mathrm{W}\end{array}$ \\
\hline Córdoba & Montería & 18 & 1225 & 66 & 27.4 & $\begin{array}{l}8^{\circ} 46^{\prime} 41.4^{\prime \prime} \mathrm{N} 75^{\circ} 58^{\prime} 26.3^{\prime \prime} \mathrm{W} \\
8^{\circ} 47^{\prime} 59.3^{\prime \prime} \mathrm{N} 75^{\circ} 57^{\prime} 17.1^{\prime \prime} \mathrm{W} \\
8^{\circ} 48^{\prime} 34.6^{\prime \prime} \mathrm{N} 75^{\circ} 56^{\prime} 20.6^{\prime \prime} \mathrm{W}\end{array}$ \\
\hline
\end{tabular}

R. $H$ relative humidity, $T$ temperature in ${ }^{\circ} \mathrm{C}$, mas/ meters above sea level

flow of ants (100\%) in the anthills evaluated at week 14, contrasting with that obtained by the commercial biological formulations Mycobac (T. lignorum) and Mycotrol (B. bassiana), where reduction in the flow of ants was observed between 74 and $86 \%$ respectively; These differences could be associated with the mechanism of action of the fungal species. In the case of Mycobac, the controlling effect on the antigenic population is determined by the capacity of T. lignorum on L. gongylophorus [38-41]; the progressive infection would explain the reduction in observed ant flow (between 74.13 and $77.17 \%$ ) in the trials with this bioform. Additionally, in Mycotrol, the reduction of ant flow is related to the entomopathogenic nature of $B$. bassiana [41, 42], which can infect the ant population or the queen ant. It was observed in the test: university campus, the reduction of the flow of ants between 86.10 and $89.96 \%$, without identifying the elimination of the anthill, which suggests that there was 
Table 3 Effectiveness of the formulations in the Tests on university campus

\begin{tabular}{|c|c|c|c|c|c|}
\hline Treatment & $\mathrm{n}$ & Week 1 & Week $6^{1}$ & Week $12^{2}$ & Week $14^{3}$ \\
\hline \multicolumn{6}{|c|}{ Trichoderma lignorum (Mycobac) } \\
\hline R4 & 5 & 100 & $\begin{array}{l}66.67+2.09 \\
b c\end{array}$ & $\begin{array}{l}32.07 \pm 1.52 \\
\text { de }\end{array}$ & $22.83+0.76 d$ \\
\hline R5 & 5 & 100 & $71.34+3.29 c$ & $\begin{array}{l}31.96 \pm 2.39 \\
d\end{array}$ & $23.60+0.8 d$ \\
\hline R6 & 5 & 100 & $78.91+2.83 d$ & $35.87 \pm 1.88 \mathrm{e}$ & $25.87+0.91 c$ \\
\hline \multicolumn{6}{|c|}{ Beauveria Bassiana (Mycontrol) } \\
\hline R1 & 5 & 100 & $59.50+4.62 b$ & $\begin{array}{l}13.45+2.02 \\
b\end{array}$ & $13.90+0.90 b$ \\
\hline R2 & 5 & 100 & $48.82+4.6 a$ & $\begin{array}{l}15.65+2.45 \\
b\end{array}$ & $12.90+1.58 b$ \\
\hline R3 & 5 & 100 & $51.61+3.79 a$ & $\begin{array}{l}16.27+1.65 \\
b\end{array}$ & $10.04+0.71 f$ \\
\hline \multicolumn{6}{|c|}{ Formulation A } \\
\hline R9 & 5 & 100 & $48.6+1.96 a$ & $3.88+0.86 a$ & 0 \\
\hline R10 & 5 & 100 & $50.84+150 a$ & $1.86+1.73 \mathrm{a}$ & 0 \\
\hline R11 & 5 & 100 & $45.22+0.86 a$ & $2.72+1.57 a$ & 0 \\
\hline \multicolumn{6}{|l|}{ Control } \\
\hline R7 & 5 & 100 & $e^{101.57+4.10}$ & $\underset{c}{122.85}+1.34$ & $130.06+1.65 e$ \\
\hline R8 & 5 & 100 & $\begin{array}{l}109.02+4.34 \\
\mathrm{e}\end{array}$ & $\begin{array}{l}124.27+1.83 \\
c\end{array}$ & $131.31+0.82 \mathrm{e}$ \\
\hline
\end{tabular}

The values correspond to the flow rate (percentage) of ants, calculated with respect to the value of week $1, \pm$ standard deviation, $R$ nest

Equal letters identify groups with similar means (Tukey $a=0.05$ )

${ }^{1} \mathrm{~F}=3076.408 \mathrm{df}=10 \mathrm{p}=0.0001$

${ }^{2} \mathrm{~F}=3080.971 \mathrm{df}=10 \mathrm{p}=0.0001$

${ }^{3} \mathrm{~F}=11,934.834 \mathrm{df}=7 \mathrm{p}=0.0001$ no infection in the queen ant. The literature reports other studies where they identified different factors that inhibit the controlling activity of $B$. bassiana, among which are the presence in the cuticle of insects, presence of bacteria such as Wolbachia, Streptomyces, secretion of antifungal substances [19, 37, 43]. The presence of yeast species that inhibit the growth of entomopathogenic fungi $[26,44]$ that, although they do not completely inhibit the entomopathogenic fungus, allow the anthill to opt for other strategies to contain the infection, among which are the removal of infected individuals, among others [19]. The differences between the commercial biological formulations of Mycobac (T. lignorum) and Mycotrol (B. bassiana) with respect to the formulation A, could be associated to that in the formulation $A$ the spores of these two fungal species are mixed (B. bassiana and $T$. lignorum), which allows the involvement of the ants and the symbiont $L$. gongylophorus [36], increasing the effect on the control of ant flow.

Different studies have evaluated the activity of fungal spores as inhibitors of leafcutter ants. For example, the effect of spores of B. bassiana strain ZGNKY-5 in a liquid suspension $\left(1 \times 10^{8}\right.$ spore $\left./ \mathrm{ml}\right)$ on Solenopsis invicta nests was evaluated. These nests were located in Panyu, Guangzhou, and the biocontrol achieved $100 \%$ effectiveness at doses between $5 \times 10^{10}$ at $1 \times 10^{11}$ spore $/ \mathrm{ml}$ (500 to $1000 \mathrm{ml}$ ), which were applied to nests in areas smaller than $10 \mathrm{~m}^{2}$ [45]. Additionally, a study on $A$. cephalotes nests (areas $<50 \mathrm{~m}^{2}$ ) located in Girardota (also evaluated in this study) and Barbosa, evaluated spores of $M$. anisopliae and T. viride, which

Table 4 Effectiveness of the formulation A in the field, by location in the different weeks of evaluation

\begin{tabular}{|c|c|c|c|c|c|c|c|c|c|c|}
\hline \multirow[t]{2}{*}{ Location } & \multirow[t]{2}{*}{$\mathrm{n}$} & \multicolumn{3}{|c|}{ Small nest (Área $<10 \mathrm{~m}^{2}$ ) } & \multicolumn{3}{|c|}{ Medium nest $\left(10 \mathrm{~m}^{2}<50 \mathrm{~m}^{2}\right)$} & \multicolumn{3}{|c|}{ Large nest (Área > $50 \mathrm{~m}^{2}$ ) } \\
\hline & & Week 4 & Week 8 & Week 12 & Week 4 & Week 8 & Week 12 & Week 4 & Week 8 & Week 12 \\
\hline Antioquia yolombo & 6 & $2.3 \pm 1.00$ & 0 & 0 & $15.4 \pm 1.92$ & $0.1 \pm 0.12$ & 0 & $60.8 \pm 1.07$ & $20.4 \pm 0.77$ & 0 \\
\hline Antioquia Girardota & 3 & 0 & 0 & 0 & $13.2 \pm 0.68$ & 0 & 0 & $56.3 \pm 0.80$ & $12.8 \pm 0.72$ & 0 \\
\hline Choco Atrato & 3 & & & & $68.2 \pm 0.88$ & 100 & 100 & $96 \pm 1.11$ & 100 & 100 \\
\hline Choco Lloro & 4 & & & & $48.1 \pm 0.99$ & 100 & 100 & $93.8 \pm 1.68$ & 100 & 100 \\
\hline Córdoba Montería & 3 & 0 & 0 & 0 & & & & & & \\
\hline Cundinamarca Tocaima & 4 & $1.6 \pm 1.31$ & 0 & 0 & $8.2 \pm 1.10$ & $0.6 \pm 1.10$ & 0 & & & \\
\hline Huila La Argentina & 4 & 0 & 0 & 0 & $14.9 \pm 2.31$ & 0 & 0 & & & \\
\hline Huila La Plata & 3 & 0 & 0 & 0 & $29.2 \pm 0.52$ & $7 \pm 3.49$ & 0 & & & \\
\hline Huila Tesalia & 4 & & & & $23 \pm 3.72$ & $5 \pm 2.03$ & 0 & $63 \pm 1.28$ & $19 \pm 3.24$ & 0 \\
\hline Magdalena Santa marta & 3 & $0.2 \pm 0.64$ & 0 & 0 & $13 \pm 1.31$ & & & & & \\
\hline Sucre Sincelejo & 3 & 0 & 0 & 0 & & & & & & \\
\hline Valle Caicedonia & 3 & 0 & 0 & 0 & $27 \pm 2.34$ & $4.2 \pm 0.50$ & 0 & & & \\
\hline Valle Bugalagrande & 3 & 0 & 0 & 0 & $0.6 \pm 1.77$ & 0 & 0 & & & \\
\hline Valle Buenaventura & 3 & & & & $60 \pm 2.08$ & 100 & 100 & 94 & 100 & 100 \\
\hline
\end{tabular}

The values correspond to the flow rate (percentage) of ants, calculated with respect to the value of week $1, \pm$ standard deviation 
showed $100 \%$ eradication effectiveness, except treatment with T. viride in the locality of Girardota. This result was observed after 42 weeks of evaluation, with effects observed after week 12 . The evaluation times were longer than those in our tests, in which similar effects were achieved, even in nests greater than $50 \mathrm{~m}^{2}$ in 12 weeks of evaluation. The reduction in time may be associated with the repeated inoculation of the bioinsecticide (weeks 1, 4 and 8), which increases the dose and presence of spores in the symbiotic fungi chambers. Here, the workers increase removal activity, which drastically reduces the flow of workers on the surface [46].

In this study, we observed that the bioinsecticide was not effective in the nests located in the localities of Buenaventura, Lloró and Atrato. These localities are in the Colombian Pacific region and are characterized by rainfall in annual average, of more than $7000 \mathrm{~mm}^{3}$. It rained during the application of the bioinsecticide, and as a result, the surface and entrance of the nests were washed out, which decreased the quantity of spores. Additionally, excess rainfall reduced the dosage because in nests with areas greater than $50 \mathrm{~m}^{2}$, the spores were effectively removed from the chambers by worker ants [46]. The effect of rain and the reduced effectiveness of the formulations, both experimentally tested in this study, as well as in the chemical control, were shown by the intervened communities.

Finally, reports in the literature indicate that the microbiota present on the surface of the insect, as well as that found at the intestinal level, can behave as a barrier against pathogens, behaving like an extension of the "innate immunity". Additionally, where the in vitro pathogenesis of an entomopathogenic fungus species is evaluated, they require the removal of the accompanying microbiota [35, 47], becoming a bias regarding the pathogenicity assessment of the entomopathogenic fungus; this is how the accompanying microbiota in the insect to be controlled could be part of the explanation of what was observed in field tests, where the control values (measured at exposure time) are usually higher than those found in the laboratory [43].

\section{Conclusions}

In the present study, it was demonstrated that treatment with a formulation (A) containing conidia of B. bassiana and T. lignorum presents insecticidal activity against $A$. cephalotes and can be considered for the control of this agricultural pest, presenting greater effectiveness than commercial biocontrollers of Mycobac (T. lignorum) and Mycotrol (B. bassiana). We showed the effectiveness of the bioinsecticide is related to the size of the nests; is necessary to carry out serial dosages of the experimental insecticide to guarantee the control of $A$. cephalotes. It was not effective in nests located in regions characterized by an annual rainfall of more than $7000 \mathrm{~mm}^{3}$. It should be noted that the experimental formulation made with the spores of the filamentous fungi of $B$. bassiana and $T$. lignorum was patented (A01N 65/00) and the transfer of technology is expected to all farmers that are affected by this pest.

\section{Abbreviations}

PDA: medium agar, potato, dextrose; YPD: yeast extract, peptone, dextrose; AN: nutritive agar; CIECUAE: Comité Institucional de Ética para el Cuidado y Uso de Animales en Experimentación.

\section{Acknowledgements}

We are thankful for financial support from INNPULSA-Colciencias and to Colciencias for financing later phases of the project currently under the commercial contract No. 3-1-44842 (2014-0401 COLCIENCIAS), contract 025-2016, to the Catholic University Dom Bosco (Brazil), University Institution Antonio José Camacho (Resolution 588 of August 17, 2016) and the Universidad de San Buenaventura, Cali.

We acknowledge UMATAS and the City Halls of the localities that were intervened for their support with the communities of farmers and for the experimental monitoring of the project.

\section{Authors' contributions}

All of the authors participated actively in the writing, analysis and review. All authors read and approved the final manuscript.

\section{Funding}

We are thankful the Colciencias (contract 025-2016) for their financial support.

Availability of supporting data

Not applicable.

Ethics approval and consent to participate

Not applicable.

Consent for publication

Not applicable.

\section{Competing interests}

The authors declare that they have no competing interests.

\section{Author details}

1 Biotechnology Group, Universidad de San Buenaventura-Cali, Av 122\# 6-65, Cali 76001, Colombia. ${ }^{2}$ Economy, Management, Land and Sustainable Development Group, Universidad de San Buenaventura-Cali, Av 122\# 6-65, Cali 76001, Colombia. ${ }^{3}$ Microbiology Industry and Environment Research Group (GIMIA), Universidad Santiago de Cali, Av 5 \#62-00, Cali 760035, Colombia. ${ }^{4}$ Universidad del Valle, Av 13 \#100-00, AA 25360 Cali, Colombia. ${ }^{5}$ Valorización del potencial de leveduras aisladas de la Region Centro-Oeste para uso industrial, Universidad Catolica Dom Bosco-Brasil, Campo Grande, Brazil.

Received: 23 November 2018 Accepted: 10 September 2019

Published online: 17 September 2019

\section{References}

1. Britto JS de, Forti LC, Oliveira MA de, Zanetti R, Wilcken CF, Zanuncio $J$ cola, et al. Use of alternatives to PFOS, its salts and PFOSF for the control of leaf-cutting ants Atta and Acromyrmex. Int J Res Environ Stud. 2016;3:11-92. http://www.bluepenjournals.org/ijres/pdf/2016/May/ de_Britto_et_al.pdf. 
2. Fernandez F, Castro-Huertas V, Serna F. Hormigas cortadoras de hojas de Colombia: Acromyrmex \& Atta (Hymenoptera: Formicidae). Primera ed. Fauna de Colombia. Bogota-Colombia: Universidad Nacional de Colombia; 2015. 253-70. http://ciencias.bogota.unal.edu.co/fileadmin/content/ icn/documentos/2015_Hormigas_Atta__Acromyrmex_Colombia.pdf.

3. Zanetti R, Zanuncio J, Santos J, da Silva W, Ribeiro G, Lemes P. An overview of integrated management of leaf-cutting ants (Hymenoptera: Formicidae) in Brazilian Forest plantations. Forests. 2014;5(3):439-54.

4. Dominah GA, McMinimy RA, Kallon S, Kwakye GF. Acute exposure to chlorpyrifos caused NADPH oxidase mediated oxidative stress and neurotoxicity in a striatal cell model of Huntington's disease. Neurotoxicology. 2017:60:54-69. https://doi.org/10.1016/j.neuro.2017.03.004.

5. Villar D, Gutiérrez J, Piedrahita D, Rodríguez-Durán A, Cortés-Vecino JA, Góngora-Orjuela A, et al. In vitro resistance to topical acaricides of the cattle tick Rhipicephalus (Boophilus) microplus from four regions of Colombia. Rev CES Med Vet y Zootec. 2016;11(3):58-70.

6. Qu H, Ma RX, Liu DH, Gao J, Wang F, Zhou ZQ, et al. Environmental behavior of the chiral insecticide fipronil: enantioselective toxicity, distribution and transformation in aquatic ecosystem. Water Res. 2016;105:138-46. https://doi.org/10.1016/j.watres.2016.08.063.

7. Michel N, Freese M, Brinkmann M, Pohlmann JD, Hollert H, Kammann $\mathrm{U}$, et al. Fipronil and two of its transformation products in water and European eel from the river Elbe. Sci Total Environ. 2016;568:171-9. https ://doi.org/10.1016/j.scitotenv.2016.05.210.

8. Qu H, Ma RX, Liu DH, Jing X, Wang F, Zhou ZQ, et al. The toxicity, bioaccumulation, elimination, conversion of the enantiomers of fipronil in Anodonta woodiana. J Hazard Mater. 2016;312:169-74. https://doi. org/10.1016/j.jhazmat.2016.03.063.

9. Ejaz M, Afzal MBS, Shabbir G, Serrão JE, Shad SA, Muhammad W. Laboratory selection of chlorpyrifos resistance in an Invasive Pest, Phenacoccus solenopsis (Homoptera: Pseudococcidae): cross-resistance, stability and fitness cost. Pestic Biochem Physiol. 2017;137:8-14. https://doi. org/10.1016/j.pestbp.2016.09.001.

10. Zhang B, Kong F, Wang H, Gao X, Zeng X, Shi X. Insecticide induction of O-demethylase activity and expression of cytochrome P450 genes in the red imported fire ant (Solenopsis invicta Buren). J Integr Agric. 2016;15(1):135-44.

11. Diaz Napal GN, Buffa LM, Nolli LC, Defagó MT, Valladares GR, Carpinella $M C$, et al. Screening of native plants from central Argentina against the leaf-cutting ant Acromyrmex lundi (Guérin) and its symbiotic fungus. Ind Crops Prod. 2015;76:275-80. https://doi.org/10.1016/j.indcr op.2015.07.001.

12. Morais WCC, Lima MAP, Zanuncio JC, Oliveira MA, Bragança MAL, Serrão $\mathrm{JE}$, et al. Extracts of Ageratum conyzoides, Coriandrum sativum and Mentha piperita inhibit the growth of the symbiotic fungus of leaf-cutting ants. Ind Crops Prod. 2015;65:463-6.

13. Stenberg JA, Heil M, Åhman I, Björkman C. Optimizing crops for biocontrol of pests and disease. Trends Plant Sci. 2015;20(11):698-712. https:// doi.org/10.1016/j.tplants.2015.08.007.

14. Barelli L, Moonjely S, Behie SW, Bidochka MJ. Fungi with multifunctional lifestyles: endophytic insect pathogenic fungi. Plant Mol Biol. 2016;90(6):657-64.

15. Kiong DS, Choon F, King PJ. Isolation and physical characterization of hydrophobin-like proteins (HLP) from aerial conidia of metarhizium. Am J Biochem Biotechnol Orig. 2015;11(2):66-72.

16. Aw KMS, Hue SM. Mode of infection of Metarhizium spp. fungus and their potential as biological control agents. J Fungi (Basel). 2017;3(2):30.

17. Wang C, Wang S. Insect pathogenic fungi: genomics, molecular interactions, and genetic improvements. Annu Rev Entomol. 2017;62:73-90.

18. Wang C, St. Leger RJ. A collagenous protective coat enables Metarhizium anisopliae to evade insect immune responses. Proc Natl Acad Sci. 2006;103(17):6647-52.

19. Ortiz-urquiza A, Keyhani NO. Action on the surface: entomopathogenic fungi versus the insect cuticle. Insects. 2013;4:357-74.

20. Lu HL, St. Leger RJ. Chapter 7-Insect immunity to entomopathogenic fungi. In: Lovett B, St. Leger RJ, editors. Genetics and molecular biology of entomopathogenic fungi. Cambridge: Academic Press; 2016. p. 251-85.

21. Butt TM, Coates CJ, Dubovskiy IM, Ratcliffe NA. Chapter 9-Entomopathogenic fungi: new insights into host-pathogen interactions. In: Lovett B,
St. Leger RJ, editors. Genetics and molecular biology of entomopathogenic fungi. Cambridge: Academic Press; 2016. p. 307-64.

22. Gajera H, Domadiya R, Patel S, Kapopara M, Golakiya B. Molecular mechanism of Trichoderma as bio-control agents against phytopathogen system—a review. Curr Res Microbiol Biotechnol. 2014;1 (4):133-42.

23. Infante D, Martínez B, González N, Yusimy R. Artículo reseña fitopatógenos Trichoderma mechanisms of action against phytopathogen fungi. Rev Protección Veg. 2009;24(1):14-21.

24. Steyaert JM, Ridgway HJ, Elad Y, Stewart A. Genetic basis of mycoparasitism: a mechanism of biological control by species of Trichoderma. N Zeal J Crop Hortic Sci. 2003;31(4):281-91.

25. Abbas A, Jiang D, Fu Y. Trichoderma Spp. as antagonist of Rhizoctonia solani. J Plant Pathol Microbiol. 2017;8:3.

26. Olmedo V, Casas-Flores S. Chapter 32-Molecular mechanisms of biocontrol in Trichoderma spp. and their applications in agriculture. Biotechnology and biology of Trichoderma. Amsterdam: Elsevier; 2014. p. 429-54.

27. Lacey LA. Chapter 1-Entomopathogens used as microbial control agents BT-microbial control of insect and mite pests. Microbial control of insect and mite pests from theory to practice. Cambridge: Academic Press; 2017. p. 3-12.

28. Greenfield M, Gómez-Jiménez MI, Ortiz V, Vega FE, Kramer M, Parsa S. Beauveria bassiana and Metarhizium anisopliae endophytically colonize cassava roots following soil drench inoculation. Biol Control. 2016;95:40-8.

29. Jirakkakul J, Roytrakul S, Srisuksam C, Swangmaneecharern P, Kittisenachai S, Jaresitthikunchai J, et al. Culture degeneration in conidia of Beauveria bassiana and virulence determinants by proteomics. Fungal Biol. 2017;122:156-71.

30. Miranda-Hernández F, Angel-Cuapio A, Loera-Corral O. 33_-Production of fungal spores for biological control A2 -Pandey, Ashok. In: Negi S, Soccol CRBT-CD in B and B, editors. Amsterdam: Elsevier; 2017. p. 757-79.

31. Barnett HL, Hunter B. Illustrated genera of imperfect fungi, 4th edn. Amer Phytopathological Society; 1998. p. 1-59.

32. Fernández F, Trujillo J, Lopez I, Pascoli M, Cuervo R. Bioformulado de Beauveria bassiana (ATCC MYA-4886) y Trichoderma lignorum (ATCC8751) como biocontrolador de Atta cephalotes * Bioinsecticide study for controlling the carrier ant (Atta cephalotes), using filamentous fungi spores Beauveria bassiana. Entramado. 2019;15(1):288-96.

33. Lemus Y, Roman G, Cuervo R, Durán J, Antonio J, Zuluaga C, et al. Determinación de la factibilidad del hongo Metarhizium anisopliae para ser usado como control biológico de la hormiga arriera (Atta cephalotes). Rev científica Guillermo Ockham. 2008;6(1):91-8.

34. Sun M, Ren Q, Guan G, Li Y, Han X, Ma C, et al. Effectiveness of Beauveria bassiana sensu lato strains for biological control against Rhipicephalus (Boophilus) microplus (Acari: Ixodidae) in China. Parasitol Int. 2013:62(5):412-5.

35. Lopez E, Orduz S. Metarhizium anisopliae and Trichoderma viride for control of nests of the fungus-growing ant, Atta cephalotes. Biol Control. 2003;27(2):194-200.

36. Lugo MA, Lugo MA, Crespo EM, Cafaro M. Hongos asociados con dos poblaciones de Acromyrmex lobicornis (Formlcldae) de san luis, argentlna MÓNICA. Bol Soc Argent Bot. 2013;48(1):5-15.

37. Montoya-lerma J, Giraldo-echeverri C, Armbrecht I, Farii-Brener A, Calle Z. Leaf-cutting ants revisited: towards rational management and control. Int J Pest Manag. 2012;58(3):37-41.

38. Verma M, Brar SK, Tyagi RD, Surampalli RY, Valéro JR. Antagonistic fungi, Trichoderma spp.: panoply of biological control. Biochem Eng J. 2007;37(1):1-20.

39. do Nascimento MO, de Almeida Sarmento R, dos Santos GR, de Oliveira CA, de Souza DJ. Antagonism of Trichoderma isolates against Leucoagaricus gongylophorus (Singer) Möller. J Basic Microbiol. 2017;57(8):699-704. https://doi.org/10.1002/jobm.201600755.

40. Ortiz A, Orduz S. In vitro evaluation of Trichoderma and Gliocladium antagonism against the symbiotic fungus of the leaf-cutting ant Atta cephalotes. Mycopathol. 2001;150(150):53-60.

41. Andreadis SS, Cloonan KR, Bellicanta GS, Paley K, Pecchia J, Jenkins NE. Efficacy of Beauveria bassiana formulations against the fungus gnat Lycoriella ingenua. Biol Control. 2016;103:165-71.

42. Ullah MS, Lim UT. Laboratory evaluation of the effect of Beauveria bassiana on the predatory mite Phytoseiulus persimilis (Acari: Phytoseiidae). J Invertebr Pathol. 2017;148:102-9. 
43. Zindel R, Gottlieb Y, Aebi A. Arthropod symbioses: a neglected parameter in pest- and disease-control programmes. J Appl Ecol. 2011;48:864-72.

44. Dillon RJ, Dillon VM, Reynolds SE, Samuels RI. Ocurrence of the antibiotic producing bacterium Burkholderia sp. in colonies of the leaf-cutting ant Atta sexdens rubropilosa. FEMS Microbiol Lett. 2004;239:319-23.

45. Li J, Guo Q, Lin M, Jiang L, Ye J, Chen D, et al. Evaluation of a new entomopathogenic strain of Beauveria bassiana and a new field delivery method against Solenopsis invicta. PLOS ONE. 2016;11(6):4-11.

46. Mighell K, Van Bael SA. Selective elimination of microfungi in leaf-cutting ant gardens. Fungal Ecol. 2016;24:15-20.
47. de los Santos-Villalobos S, Guzmán-Ortiz DA, Gómez-Lim MA, DélanoFrier JP, de Folter S, Sánchez-García P, et al. Potential use of Trichoderma asperellum (Samuels, Liechfeldt et Nirenberg) T8a as a biological control agent against anthracnose in mango (Mangifera indica L.). Biol Control. 2013;64(1):37-44. https://doi.org/10.1016/j.biocontrol.2012.10.006.

\section{Publisher's Note}

Springer Nature remains neutral with regard to jurisdictional claims in published maps and institutional affiliations.
Ready to submit your research? Choose BMC and benefit from:

- fast, convenient online submission

- thorough peer review by experienced researchers in your field

- rapid publication on acceptance

- support for research data, including large and complex data types

- gold Open Access which fosters wider collaboration and increased citations

- maximum visibility for your research: over $100 \mathrm{M}$ website views per year

At BMC, research is always in progress.

Learn more biomedcentral.com/submissions 